\title{
Confirmation of 'Medjool' Date as a Landrace Variety through Genetic Analysis of 'Medjool' Accessions in Morocco
}

\author{
Mohammed Aziz Elhoumaizi \\ Department of Biology, University of Mohammed 1st Faculty of Science, BP 724, Oujda, Morocco \\ Panchanoor S. Devanand ${ }^{1}$, Jinggui Fang, and Chih-Cheng T. Chao ${ }^{2}$
Department of Botany and Plant Sciences, University of California-Riverside, Riverside,
CA 92521-0124
}

AdDitional INDEX wORDs. AFLP, dendogram, genetic similarity, germplasm, Phoenix dactylifera, principal coordinate analysis, UPGMA

\begin{abstract}
We studied 66 'Medjool' date palm (Phoenix dactylifera L.) accessions from Morocco, six varieties of dates from Egypt, and four 'Medjool' accessions and one 'Deglet Noor' accession from California to investigate the hypothesis that 'Medjool' is a landrace variety in Morocco. We used four sets of fluorescent-labeled amplified fragment length polymorphism (AFLP) markers to examine these accessions. A total of 402 bands were generated, of which 217

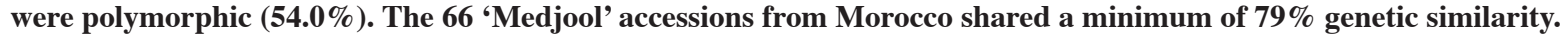
These results support the hypothesis that 'Medjool' is a landrace variety in Morocco and it is not genetically uniform. 'Medjool' is the first confirmed landrace variety of date palm in the world. This finding raises the possibility that other date palms may be landrace varieties in different growing areas. Confirmation of a landrace variety in date palm has significant implication for future date palm germplasm collection and preservation. The mechanism(s) generating the genetic variation within 'Medjool' accessions remains unknown. One possibility is that spontaneous genetic changes could occur frequently within vegetative tissues like offshoots under high temperature and drought stress.
\end{abstract}

Date palm $(2 \mathrm{n}=2 \mathrm{x}=36)$, a dioecious perennial monocotyledon, is the most important fruit crop in the arid climate regions of North Africa and the Middle East. In addition, there is date production in China, India, Pakistan, Spain, and California (Food and Agriculture Organization of the United Nations, 2004). 'Medjool' (also called 'Medjhool', 'Medjehuel', 'Mejhul', or 'Mejhoul') produces large soft fruit, with orange-yellowish flesh, and a mildly rich and pleasing flavor. 'Medjool' fruit have a unique appearance from other date palm fruit and are highly prized in markets around the world. The origin of 'Medjool' is known to be from the valley of Tafilalet (Errachidia) in Morocco (Nixon, 1950). Genetically, 'Medjool' belongs to the major group of date accessions from North Africa that include other varieties such as 'Deglet Noor' (origin of Algeria/Tunisia) and varieties from Egypt (El-Assar et al., 2005). Planting of 'Medjool' and other varieties in Morocco and Algeria was severely diminished by the bayoud disease (abiadh in Arabic) caused by the fungus Fusarium oxysporum Schlechtend.:Fr. f. sp. albedinis (Killian \& Maire) Gordon (Elmer et al., 1968). Date palm commonly is propagated vegetatively using offshoots (Nixon and Carpenter, 1978). Plants derived from offshoots of the same variety are considered genetically identical to each other and to their "mother" plants.

Genetic diversity and relationships among different date palm accessions in different countries or regions have been reported using different types of markers such as morphology (Jaradat and Zaid, 2004), isozymes (Bendiab et al., 1998), restriction fragment length polymorphism (RFLP) (Corniquel and Mercier, 1997), random amplified polymorphic DNA (RAPD) (Sedra et

Received for publication 8 Nov. 2005. Accepted for publication 12 Dec. 2005. ${ }^{1}$ Current address: Dept. of Earth and Environmental Science, Univ. of Texas at San Antonio, 6900 N. Loop 1604, San Antonio, TX 78249.

${ }^{2}$ Corresponding author: C.T. Chao, Phone: 951-827-3441; Fax: 951-827-4437; e-mail: ctchao@citrus.ucr.edu al., 1998), or AFLP markers (Cao and Chao, 2002; El-Assar et al., 2005; Jubrael et al., 2005). Over 220 varieties of dates are present in Morocco (Toutain et al., 1971). Sedra et al. (1998) were able to identify 25 Moroccan date varieties using RAPD markers; however, the level of polymorphism was low using RAPD markers. Elhoumaizi et al. (2002) were able to use 26 vegetative traits to differentiate 26 date varieties from Morocco, including 'Medjool'. Some morphological characters were highly correlated with each other and possibly associated with resistance to bayoud disease.

Most studies of date palm germplasm have included a single accession of named varieties in the studies. This approach allows the detection of inter-varietal genetic variation but does not address the issue of intra-varietal variation. Vorster et al. (2002) analyzed the sequences of repetitive DNA sequences from 'Barhee' and 'Medjool' accessions and found variation in sequences within both accessions. They suggested that 'Medjool'may have a higher level of methylation in the repetitive sequences and 'Barhee' may have a higher level of sequence variation than 'Medjool', through asexual (offshoot) propagation. A previous study of 'Medjool' and 'Deglet Noor' accessions in California using AFLP marker showed there were large intra-varietal genetic variations among 23 'Medjool' accessions and almost no variation among the 33 'Deglet Noor' accessions (Devanand and Chao, 2003). The large genetic variability among 'Medjool' accessions led to the hypotheses that either 'Medjool' is a landrace variety from Morocco, or 'Medjool' has a very high mutation rate through asexual propagation (offshoots). A landrace variety is defined as a mixture of genotypes that evolved, largely by natural selection, under the environmental conditions in which they were grown (Harlan, 1975).

AFLP markers are based on polymerase chain reaction (PCR) (Vos et al., 1995) and produce high polymorphisms and reliability. 
They have been used extensively to study the genetic relationships and diversity of plant species (Devanand et al., 2004; Lucchini, 2003; Mueller and Wolfenbarger, 1999), mapping (Asnaghi et al., 2004; Peters et al., 2004), or tracking pollen flow in orchards (Chao et al., 2005). To investigate the hypothesis that 'Medjool' is a landrace variety, we collected leaf samples of 66 accessions of 'Medjool' from three locations in the Tafilalet Valley of Morocco, obtained from three different sources: 1) plants derived from tissue culture, 2) plants from offshoots, and 3) mature plants. We then used AFLP markers to study the genetic variability among these Moroccan 'Medjool' accessions and also to compare them with date accessions from Egypt and California.

\section{Materials and Methods}

Plant materials. All Moroccan 'Medjool' accessions were collected from three locations in Morocco, the Office Regional de Mis en Valeur (ORMVA) Morocco experimental stations at Errachidia and Borouk (10 km southeast of Errachidia, Morocco), or Zreigate (Aoufous) (60 km southwest of Errachidia in the area where 'Medjool' is believed to have originated). Ten accessions (no. 1-10) were 'Medjool' plants derived from tissue culture; however, the relationships among the parents of these 10 plants was unknown. The detail of the tissue culture process involved was unknown. Twenty-seven accessions (no. 11-37) were mature 'Medjool' trees known by local farmers and M.A. Elhoumaizi. Twenty-nine accessions (no. 38-66) were offshoots from known 'Medjool' palms collected from the three locations. One accession of 'Deglet Noor' [U.S. Dept. of Agriculture, National Clonal Germplasm Repository (NCGR) no. 2157]; and four accessions of 'Medjool' (NCGR no. 2119, 2134, 2186, and 2195 ) from California plus one accession each of 'Bartmounda', 'Bint Aisha', 'Halway', 'Hayany', 'Sammany', and 'Siwi' from Egypt were included in the study for comparison (El-Assar et al., 2005) (Table 1).

AFLP REACTIONS AND DATA ANALYSIS. AFLP analysis was performed as described in Chen et al. (2004). Briefly, total DNA was extracted from young leaves using the DNeasy system (Qiagen, Valencia, Calif.). AFLP analysis was conducted using the GIBCO BRL AFLP System II (Life Technologies, Grand Island, N.Y.) and visualized with the LI-COR IR automated sequencer 4000-L (LI-COR, Lincoln, Nebr.). Total DNA (125 ng) from all samples was digested with a 1- $\mu \mathrm{L}$ mixture of EcoRI/MseI (1.25 units $/ \mu \mathrm{L})$ at $37^{\circ} \mathrm{C}$ overnight and ligated to $E c o \mathrm{RI} / M$ se I adapters with $1.5 \mu \mathrm{L}$ ( 1 unit/ $\mu \mathrm{L})$ of T4 DNA ligase at $25^{\circ} \mathrm{C}$ for at least 6 h. Pre-amplification reactions were performed on a MJR Cycle LR (MJ Research, Watertown, Mass.). The pre-amplified PCR product was quantified in the fluorometer, the amount of template for subsequent PCR was diluted to $125 \mathrm{ng} \cdot \mu \mathrm{L}^{-1}$, and selective amplification was performed.

The selective amplification PCRs were performed by another touchdown program described by Chen et al. (2004). Both preand selective-amplification conditions were modified according to Myburg et al. (2001). The products from the selective amplification were electrophoresed on $25 \mathrm{~cm} \times 0.25 \mathrm{~mm} 8 \%$ denaturing polyacrylamide Long Ranger Gel Solution (BMA, Rockland, Maine) in $0.8 \times$ TBE buffer using a LI-COR automated sequencer 4000-L. Based on previous studies of date palm using AFLP markers (Cao and Chao, 2002; Devanand and Chao, 2003), six EcoRI +2 bases / $M s e \mathrm{I}+3$ bases primer sets (IRD700 E + TA/M + CAG; IRD800 $\mathrm{E}+\mathrm{AC} / \mathrm{M}+\mathrm{CAG} ; \mathrm{IRD} 700 \mathrm{E}+\mathrm{TG} / \mathrm{M}+\mathrm{CAT} ; \mathrm{IRD} 800 \mathrm{E}+\mathrm{AG} / \mathrm{M}$ + CAT; IR700 E + GC/M+CTC; IRD800 E+CA/M+CTC) that showed clear scoreable and highly polymorphic fragments were selected for fluorescent-AFLP reactions (Table 2).

DATA ANALYSIS. AFLP fragments were visually scored as present (1) or absent (0) to create the binary data set. The data were entered into a binary data matrix as discrete variables. Jaccard's coefficient of similarity (Sneath and Sokal, 1973) was calculated for all pair-wise comparisons among all the accessions and varieties. A dendrogram was generated by cluster analysis using the unweighted pair group method using the arithmetic average (UPGMA). Principal coordinate analysis (PCOA) was also carried out to show the broad multi-dimensional distribution of the varieties in a scatter-plot [NTSYS-pc, version 2.1 (Rohlf, 2000)].

\section{Results and Discussion}

AFLP analysis. A total of 402 scoreable bands were generated by six AFLP primer sets (Table 2). For all 77 accessions used in the study, the highest number of bands, 89 , was generated by primer set $\mathrm{E}+\mathrm{AG} / \mathrm{M}+\mathrm{CAT}$; primer set $\mathrm{E}+\mathrm{GC} / \mathrm{M}+\mathrm{CTC}$ had only 34 bands. The number of polymorphic bands ranged from 19 to 55 per primer with an average of 36.2 per band (54.0\%). Among all accessions of 'Medjool' (70) from Morocco and California, the polymorphic bands were 155 out of 402 bands (38.6\%) (data not shown). This level of polymorphism was very similar to the $39.7 \%$ among 23 'Medjool' accessions from California based on AFLP polymorphism (Devanand and Chao, 2003). These levels of polymorphism (38.6\% to 39.7\%) are higher than AFLP polymorphism found among 'Medjool' plants (26.5\%) derived from tissue culture (Gurevich et al., 2005). Among 66 'Medjool' accessions from Morocco, there were 116 polymorphic bands out of 402 bands (19.3\%) (Table 2). They are all lower than the levels of AFLP polymorphism used in studying different varieties of date palm from Egypt, 66.6\% (El-Assar et al., 2005). The genetic polymorphism among 'Medjool' accessions from Morocco is much lower (see discussion in next section). The AFLP marker is a very efficient system for identification and differentiation of date palm accessions from different countries or origins. The biggest advantage of the AFLP marker system is the ability to generate a large number of markers compared to other marker systems like isozyme or RAPD. However, the levels of polymorphism among different marker systems for date palms are very similar. For examples, seven polymorphic bands were found among 16 alleles from seven isozymes in a study of dates from Algeria (43.8\% polymorphic) (Bennaceur et al., 1991); there were only 54 bands from 19 RAPD primers in a study of Moroccan date varieties, but 37 were polymorphic bands (68.5\%) (Sedra et al., 1998). AFLP markers, like some other molecular markers, can be applied to study tissues from juvenile sources like offshoots or propagations from tissue culture, unlike many morphological markers that can only be evaluated 4-5 years after planting.

Genetic Variability Within 'Medjool' From Morocco. The dendogram based on the UPGMA and the scatter diagram based on the PCOA of 77 date accessions were shown in Figs. 1 and 2, respectively. The DNA samples of 'Medjool' used in this study came from three sources: tissue culture of in vitro plants, mature plants and offshoots. All 70 accessions of 'Medjool' (66 from Morocco and four from California) could be divided into four groups based on their AFLP polymorphisms: cluster I, cluster II, cluster III and others. Cluster I has 32 accessions of 'Medjool,' including six in vitro plants and 22 mature plants from Morocco, and four 'Medjool' accessions from California. None of the six accessions from tissue culture has exactly the 
Table 1. Variety name, number, location of collection site or origin, and types of plants used in the study of 77 date palm accessions.

\begin{tabular}{llll}
\hline Variety & \multicolumn{1}{c}{ Accession no. } & Location of origin & Type of plants \\
\hline Medjool & $1-6$ & Borouk, Morocco & In vitro plants \\
Medjool & $7-10$ & Errachidia, Morocco & In vitro plants \\
Medjool & $11-37$ & Errachidia, Morocco & Mature trees \\
Medjool & $40,54,61$ & Errachidia, Morocco & Offshoots \\
Medjool & $38-39,41-53,55-60,62-66$ & Zreigate, Morocco & Offshoots \\
Medjool & NCGR ${ }^{\text {No. } 2119(M 1)}$ & California & Mature tree \\
Medjool & NCGR No. 2134 (M2) & California & Mature tree \\
Medjool & NCGR No. 2186 (M3) & California & Mature tree \\
Medjool & NCGR No. 2195 (M14) & California & Mature tree \\
Deglet Noor & & California & Mature tree \\
Bartmounda & & Egypt & Mature tree \\
Bint Aisha & & Egypt & Mature tree \\
Halway & & Egypt & Mature tree \\
Hayany & & Egypt & Mature tree \\
Sammany & & Egypt & Mature tree \\
Siwi & & Egypt & Mature tree \\
\hline ZNCGR No & & Clont Germplasm Repostory nuber.
\end{tabular}

zNCGR No. = U.S. Dept. of Agriculture, National Clonal Germplasm Repository number.

Table 2. AFLP primer sets; total number of AFLP bands scored used in the study of date palm accessions from Morocco, Egypt, and California; and the number and percentage of polymorphic AFLP bands identified among all 77 date accessions and among 66 'Medjool' accessions from Morocco.

\begin{tabular}{lccc}
\hline & \multicolumn{3}{c}{ Polymorphic AFLP bands [no. (\%)] } \\
\cline { 2 - 4 } Primer sets & $\begin{array}{c}\text { Total band } \\
\text { scored (no.) }\end{array}$ & $\begin{array}{c}\text { All 77 } \\
\text { accessions }\end{array}$ & $\begin{array}{c}\text { All 66 Moroccan } \\
\text { 'Medjool' accessions }\end{array}$ \\
\hline E+TA/M+CAG & 49 & $21(43.8 \%)$ & $8(16.3 \%)$ \\
E+AC/M+CAG & 67 & $34(50.7 \%)$ & $15(22.4 \%)$ \\
E+TG/M+CAT & 75 & $37(49.3 \%)$ & $13(17.3 \%)$ \\
E+AG/M+CAT & 89 & $55(61.8 \%)$ & $41(46.1 \%)$ \\
E+GC/M+CTC & 34 & $19(55.9 \%)$ & $8(23.5 \%)$ \\
E+CA/M+CTC & 88 & $51(58.0 \%)$ & $31(35.2 \%)$ \\
Total & 402 & 217 & 116 \\
Average & 67 & $36.2(54.5 \%)$ & $19.3(28.9 \%)$ \\
\hline
\end{tabular}

same AFLP profile, with each other or with any other accessions. Twenty mature 'Medjool' accessions plus in vitro plant no. 6 have highly similar AFLP polymorphisms. In fact, four groups within this cluster have the same polymorphisms (no. 13 and 25; no 24, 27, 28, and 29; no. 18, 19 and 21; no. 31 and 32) (Fig. 1). Accession no. 12 and 15 from Morocco, and M1, M2, M3, and M14 from California have few differences in banding profiles compared with the other 26 accessions in cluster I (Figs. 1 and $2)$. The four 'Medjool' accessions from California share lower levels of similarity (0.71-0.79) compared to all the 'Medjool' accessions from Morocco (similarities from 0.79 to 1 ). Cluster II has 31 accessions including two mature plants and 29 offshoots from Morocco. Three groups of the accessions within this cluster have the same profiles: (1) no. 50 and 52; (2) no 61 and 62 ; (3) no. 37 (mature plant), no. $38,39,40,41,42,43,44,45,46,48$, 55 , and 59 (all offshoots). The other 14 accessions have similar but not identical AFLP profiles. Cluster III contains only four accessions from tissue culture origin, accession no. 7, 8, 9, and 10 (with Jaccard's similarity ranging from 0.98 to 1 ). Accessions no. 8 and 9 have identical AFLP profiles. All four accessions share $0.79-0.82$ similarity with other 'Medjool' accessions from Morocco, and 0.71-0.78 similarity with four 'Medjool' accessions from California. These four tissue culture-derived accessions showed the largest AFLP profile difference compared with all other 'Medjool' accessions from Morocco and California. This large difference may have been caused by genetic variation (somaclonal variation) generated during the tissue culture processes or the other possibility is that these accessions were mislabeled during propagation processes. Tissue culture processes, especially embryogenesis, are known to generate large genetic variation in date palms (Azeqour et al., 2002). Three other accessions (no. 14, 26, and 65) did not position near other 'Medjool' accessions based on the AFLP polymorphisms (Fig. 2). They share $0.79-0.92$ similarity with other 'Medjool' or among themselves.

Relationship between Moroccan 'MedJool' aCCESSIONS AND DATE ACCESsions from Egypt and California. Six date varieties from Egypt (Bartmounda, Siwi, Sammany, Hayany, Bint Aisha, and Halawy) and one California 'Deglet Noor' accession were included in this study for comparison. 'Bartmounda', 'Deglet Noor', and 'Medjool' belong to the major date germplasm cluster in North Africa (ElAssar et al., 2005). 'Siwi', 'Sammany', 'Hayany', and 'Bint Aisha' represent four minor clusters within North Africa date germplasm. 'Halawy' has a hybrid origin among the clusters. The results from this study show that all 'Medjool' accessions from Morocco share $0.79-0.82$ similarity with 'Bartmounda' and 0.79-0.85 similarity with 'Deglet Noor'. These similarities confirm that all 'Medjool' accessions from Morocco examined in this study belong to the major date palm germplasm of North Africa.

'Medjool' as a LANDRACE VARIETy AND IMPLICATION FOR DATE GERMPLASM RESOURCES. The previous study of 'Medjool' accessions from California raised the possibility that 'Medjool' exists as a landrace variety in Morocco (Devanand and Chao, 2003), which is the origin of 'Medjool' and the origin of offshoots exported to California since 1927 (Swingle, 1945). Examining 66 accessions of 'Medjool' from Morocco using six AFLP primer sets, we have showed that many 'Medjool' accessions have different AFLP polymorphisms. These results confirm the previous hypothesis that 'Medjool' exists as a landrace variety in Morocco (Devanand and Chao, 2003). Genetically, a large portion of the 'Medjool' plants in Morocco are similar, but not the same. There could be potentially unlimited numbers of different genotypes of 'Medjool' existing in Morocco. However, they could exhibit similar phenotypes, for example, fruit shape, fruit color and fruit texture, therefore all genotypes are continuously propagated by farmers in Morocco.

The origin of the 'Medjool' landrace variety in Morocco is unclear. How the genetic variation was originally created is unknown but there are several possibilities. The first possibility is that the genetic variation may have resulted from a mixture of seedlings germinated from seeds instead of offshoots. Offshoots, developed at the base of young date palms, are of clonal/vegetative origin and assumed to have the same genetic constituents as the parental trees. Commonly, seeds (from sexual hybridization) 


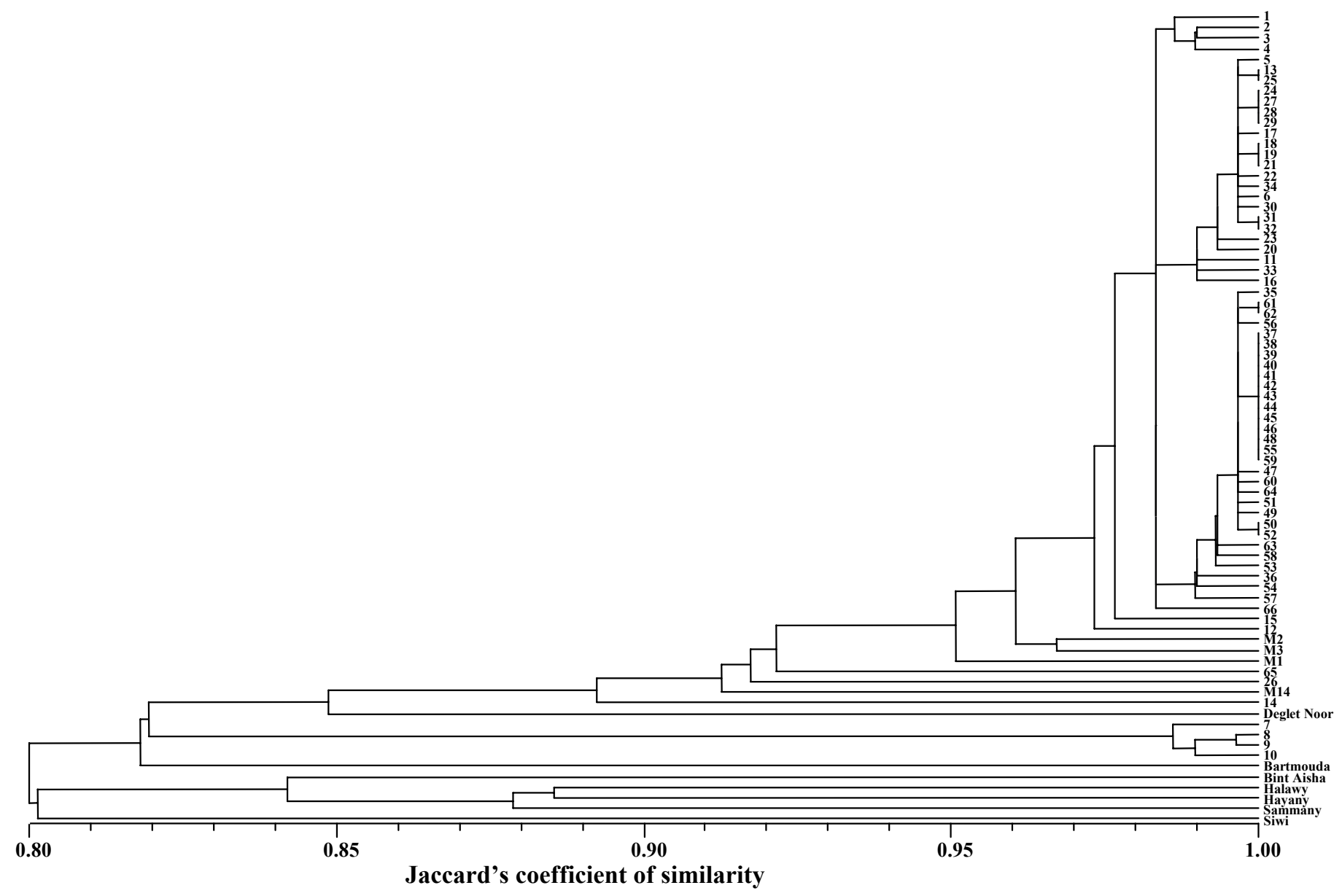

Fig. 1. Dendrogram of 66 'Medjool' date palm accessions from Morocco, one 'Deglet Noor' accession, and four 'Medjool' accessions from California, and six varieties from Egypt resulting from an UPGMA cluster analysis based on Jaccard's estimates of similarity obtained from AFLP polymorphisms.

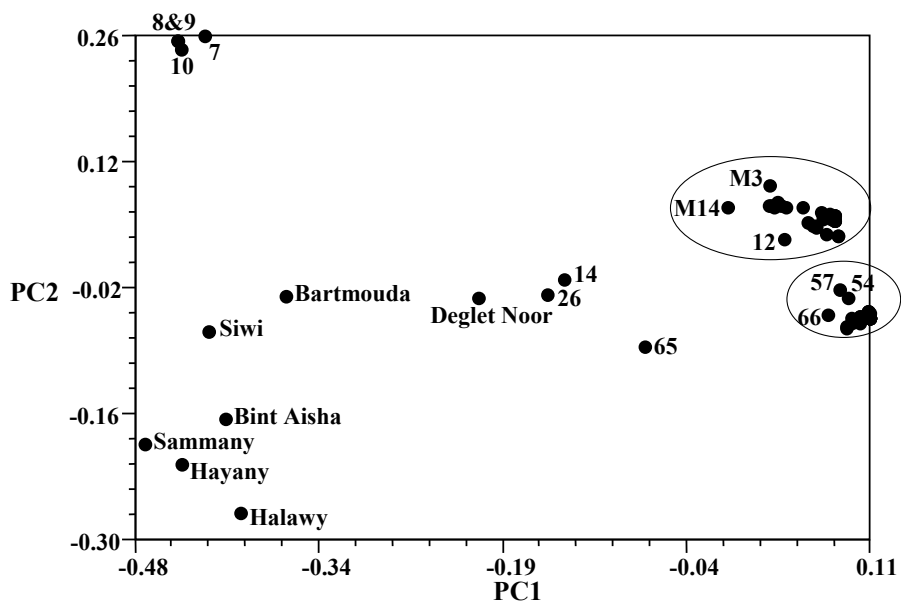

Fig. 2. Scatter diagram of the first two principal coordinates (PC1 and PC2) from PCOA of 66 'Medjool' date palm accessions from Morocco, one 'Deglet Noor' accession, and four 'Medjool' accessions from California, and six varieties from Egypt based on 402 AFLP bands.

borne in the canopy tops may drop and begin to germinate near the base of the trees. These seedlings germinated from seeds (also known as "khalts," "sairs," "deguouls," or "mantours") could be propagated as offshoots by mistake, due to the close proximity. However, if this is the cause of the genetic variation, we should find larger genetic variation, for example, $50 \%$ similarity in the
F1 compared with the maternal genotypes. However, if the pollen parents are F1 "khalts" from the previous generation, then the seedlings germinated from seeds from this generation should share $75 \%$ similarity with the maternal parents; they are in fact backcross 1 progenies. It is possible that the genetic variation within some mature 'Medjool' plants could derive from this type of mechanism. However, most researchers and professional propagators are aware of this issue, therefore care is always given during offshoot propagation. The possibility that mixing seedlings germinated from seeds during offshoot propagation could be the cause of genetic variation of a landrace variety is minimal, but not totally impossible. The second possible mechanism that might cause genetic variation within a date palm landrace variety is that date palms, especially 'Medjool', may have relatively high rates of somatic genetic mutation and large genetic variation could accumulate through generations of vegetative, offshoot, propagation. The date palm is known to experience a high rate of genetic change after going through the tissue culture processes, especially 'Medjool' (Gurevich et al., 2005). A high percentage (up to 75\%) of date trees derived from tissue culture may have variegation in leaves, variation in leaf structure and overall plant growth patterns, produce no inflorescences or abnormal floral development, or produce seedless parthenocarpic fruits (Al-Wasel, 2001). This high level of mutation during the tissue culture processes suggests that date palms, especially 'Medjool', could have a higher than normal mutation rate under natural environments, especially under high-temperature heat stress or drought stress. In many 
date-producing countries, the temperature during the summer can exceed $50{ }^{\circ} \mathrm{C}$, even reach $60{ }^{\circ} \mathrm{C}$ in some instances.

'Medjool' is the first confirmed landrace variety of date palm in the world. The existence of a landrace variety will change how we study, collect and maintain date palm germplasm in the future. Considering the fact that a landrace variety of date palm exits, researchers need to study multiple accessions of the same variety in the future. If genetic variation within the landrace date palm variety was the result of environmental stresses, different strains of the same variety may exist at different locations. Researchers should study multiple accessions of the same variety from different locations/environments. Different strains of the landrace variety offer the possibility that different phenotypic traits, such as resistance to bayoud disease or better fruit quality, may exist within the landrace variety. Future date palm breeding or selection programs should consider exploring this genetic variability. From the date germplasm resource point of view, a gene bank may need to collect a core number of accessions of the same landrace variety from the center of origin or different environments/countries to ensure a comprehensive representation of the variety. The first step towards this goal is to study multiple accessions of the same variety from different sources and identify the extent of the variation as illustrated in our study.

\section{Literature Cited}

Al-Wasel,A.S. 2001. Somaclonal variation in tissue culture-derived date palm (Phoenix dactylifera) trees. HortScience 36:457 (Abstr.).

Asnaghi, C., D. Roques, S. Ruffel, C. Kaye, J.-Y. Hoarau, H. Telismart, J.C. Girard, L.M. Raboin, A.M. Risterucci, L. Grivet, and A. D'Hont. 2004. Targeted mapping of a sugarcane rust resistance gene (Bru1) using bulked segregant analysis and AFLP markers. Theor. Appl. Genet. 108:759-764.

Azeqour, M., K. Majourhat, and M. Baaziz. 2002. Morphological variations and isoenzyme polymorphism of date palm clones from in vitro culture acclimatized and established on soil in south Morocco. Euphytica 123:57-66.

Bendiab, K., M. Baaziz, and K. Majourhat. 1998. Preliminary date palm variety composition of Moroccan palm groves as revealed by leaf isoenzyme phenotypes. Biochem. Systematics Ecol. 26:71-82.

Bennaceur, M., C. Lanaud, M.H. Chevalier, and N. Bounaga. 1991. Genetic diversity of the date palm (Phoenix dactylifera L.) from Algeria revealed by enzyme markers. Plant Breeding 107:56-69.

Cao, B.R. and C.T. Chao. 2002. Identification of date palm cultivars in California using AFLP markers. HortScience 37:966-968.

Chao, C.T., J. Fang, and P.S. Devanand. 2005. Long distance pollen flow in mandarin orchards determined by AFLP markers - Implication for seedless mandarin production. J. Amer. Soc. Hort. Sci. 130:374-380.

Chen, J., P.S. Devenand, D.J. Norman, R.J. Henny, and C.T. Chao. 2004. Genetic relationships of Aglaonema species and cultivars inferred from AFLP markers. Ann. Bot. 93:157-166.

Corniquel, B. and L. Mercier. 1997. Identification of date palm (Phoenix dactylifera L.) cultivars by RFLP: Partial characterization of a cDNA probe that contains a sequence encoding a zinc finger motif. Intl. J. Plant Sci. 158:152-156.

Devanand, P.S. and C.T. Chao. 2003. Genetic variation within 'Medjool' and 'Deglet Noor' date (Phoenix dactylifera L.) cultivars in California detected by fluorescent-AFLP markers. J. Hort. Sci. Biotechnol. 78:405-409.

Devanand, P.S., J.J. Chen, R.J. Henny, and C.T. Chao. 2004. Assessment of genetic relationships among Philodendron cultivars using AFLP markers. J. Amer. Soc. Hort. Sci. 129:690-697.

El-Assar, A.M., R.R. Krueger, P.S. Devanand, and C.T. Chao. 2005. Genetic analysis of Egyptian date (Phoenix dactylifera L.) accessions using AFLP markers. Genet. Resources Crop Evol. 52:601-607.

Elmer, H.S., J.B. Carpenter, and L.J. Klotz. 1968. Pests and diseases of the date palm, Part II, Diseases. Food and Agriculture Organization of the United Nations, Plant Protection Bul. 16:97-110.

Elhoumaizi, M.A., M. Saaidi, A. Oihabi, and C. Cilas. 2002. Phenotypic diversity of date-palm cultivars (Phoenix dactylifera L.) from Morocco. Genet. Resources Crop Evol. 49:483-490.

Food and Agriculture Organization of the United Nations. 2005. 2004 Worldwide dates production statistics. 29 Sept. 2005. <http://faostat. fao.org/faostat $/$ servlet $/$ XteServlet3 ? Areas $=\% 3 \mathrm{E} 862 \&$ Items $=577 \& \mathrm{El}$ ements $=51 \&$ Years $=2004 \&$ Format $=$ Table $\&$ Xaxis $=$ Years $\&$ Yaxis $=$ Cou ntries $\&$ Aggregate $=\&$ Calculate $=\&$ Domain $=$ SUA $\&$ ItemTypes $=$ Produ ction. Crops.Primary \&language $=\mathrm{EN}>$.

Gurevich, V., U. Lavi, and Y. Cohen. 2005. Genetic variation in date palms propagated from offshoots and tissue culture. J. Amer. Soc. Hort. Sci. 130:46-53.

Harlan, J.R. 1975. Crops and man. Amer. Soc. Agron., Madison, Wis. Jaradat,A.A. and A. Zaid. 2004. Quality traits of date palm fruits in a center of origin and center of diversity. Food Agr. Environ. 2:208-217.

Jubrael, J.M.S., S.M. Udupa, and M. Baum. 2005. Assessment of AFLPbased genetic relationships among date palm (Phoenix dactylifera $\mathrm{L}$.) varieties of Iraq. J. Amer. Soc. Hort. Sci. 130:442-447.

Lucchini, V. 2003. AFLP: A useful tool for biodiversity conservation and management. Biologies 326:S43-S48.

Mueller, U.G. and L.L. Wolfenbarger. 1999. AFLP genotyping and fingerprinting. Trends Ecol. Evol. 14:389-394.

Myburg, A.A., D.L. Remington, D.M. O'Malley, R.R. Sederoff, and R.W. Whetten. 2001. High-throughput AFLP analysis using infrared dye-labeled primers and an automated DNA sequencer. BioTechniquies 30:348-357.

Nixon, R.W. 1950. Imported varieties of dates in the United States. U.S. Dept. Agr. Circ. No. 834. Washington, D.C.

Nixon, R.W. and J.B. Carpenter. 1978. Growing dates in the United States. U.S. Dept. Agr. Bul. No. 207. Washington, D.C.

Rohlf, F.J. 2000. NTSYSpc, Numerical taxonomy and multivariate analysis system, Version 2.1 user guide. Exeter Software, Setauket, N.Y.

Peters, J.L., G. Cnops, P. Neyt, J. Zethof, K. Cornelis, M. Van Lijsebettens, and T. Gerats. 2004. An AFLP-based genome-wide mapping strategy. Theor. Appl. Genet. 108:321-327.

Sedra, M.H., P. Lashermes, P. Trouslot, M. Combes, and S. Hamon. 1998. Identification and genetic diversity analysis of date palm (Phoenix dactylifera L.) cultivars from Morocco using RAPD markers. Euphytica 103:75-82.

Sneath, P.H.A. and R.R. Sokal. 1973. Numerical taxonomy: The principles and practice of numerical classification. Freeman, San Francisco.

Swingle, W.T. 1945. Introduction of the Medjhool date from Africa into the United States. Date Growers' Institution Rpt. 22:15-16.

Toutain, G., A. Bachra, and A. Chari. 1971. Cartographie variétale de la palmeraie marocaine. Directeur de Recherche Agronomique, Rabat, Morocco.

Vorster, B.J., K.J. Kunert, and C.A. Cullis. 2002. Use of representational difference analysis for the characterization of sequence differences between date palm varieties. Plant Cell Rpt. 21:271-275.

Vos, P., R. Hogers, M. Bleeker, M. Reijans, T. van de Lee, M. Hornes, A. Frijters, J. Pot, J. Peleman, M. Kupier, and M. Zabeau. 1995. AFLP: A new technique for DNA fingerprinting. Nucl. Acid Res. 23:4407-4414. 